\title{
長期間水ストレスを与えた植物で発生する

\section{AE Events Issued from the Stem of Plants Under Long Term Water Stress}

\author{
Sayuri MURAKAMI*3, Youichi YAHAGI, \\ Kyoji HOMMA and Takuji KOIKE \\ ${ }^{* 3}$ Department of Mechanical Engineering and Intelligent Systems, The University of Electro Communications, \\ 1-5-1 Chofugaoka, Chofu shi, Tokyo, 1828585 Japan
}

\begin{abstract}
The influence to ecosystem of plant by global warming is investigated. However, few diagnostic technologies by non-destructive inspection to environmental stress are established. Acoustic emission $(\mathrm{AE})$ is applied to the measurement of damage under the water stress of plants. Cavitation phenomena are known by negative pressure under the lack of water in the vessel. Since shock wave due to cavitations issues $\mathrm{AE}$, water stress state of plant can be monitored on real time by measuring AE. In this paper, $\mathrm{AE}$ events by the cavitation were measured in drought treated (iinkgo biloba $L_{\text {. }}$. Ficus spp. and Lycopersicon es. In all plant, AE events are increased during drought and stopped by supplying water. In Ginkgo and Ficus, a temporary decrease of AE events was observed during drought. It is presumed that plant adjust internal water balance for self defense by a certain procedure. Stoma closing of the leaf considered being the most effective physiology, however, was not the cause.
\end{abstract}

Key Words : Acoustic Emission, Water Stress, Draught, Cavitation, Plant

\section{1. 精言}

地球温暖化による環境変化が生態系へ及ぼす影響は 大きいためその実態調査が進められているが，植物が 受ける環境ストレスを物理的に検出し，診断する技術 はほとんどないと言って良い。

種子植物は, 葉の光合成によって炭水化物を合成し, 根から水分やミネラルを吸収し，これらを維管束と呼 ばれる器官（前者は篩部, 後者は木部から成る）によ って必要な部位へ送る機構を持っている. 地中での水 分が不足すると多くの生理代謝に異常をきたす。一般 に水分が久乏して植物体に何らかの影響を及ぼすこと を水ストレスと呼んでいる。本研究は環境ストレスの ひとつである水ストレスに注目し, ストレスの大きさ と植物体内で起こる物理的変化の計測量との関係につ いて考察した.

種子植物は, 葉の裹面からの水の蒸散作用ならびに 根に働く根圧を利用して, 維管束のひとつである導管

* 原稿受付 2005 年 1 月 19 日.

*1 正員, 電気通信大学知能機械工学科( 182-8585 調布市調 布ヶ丘 1-5-1).

*2 電気通信大学大学院知能機械工学専攻

E-mail : mura-s@mce.uec.ac.jp
(または仮導管)を通し，水の凝集力によって根から 水を吸い上げている．導管は死んだ細胞である管状組 織（仮導管は紡鍾状組織）により構成されているもの で, 土㙥に含まれる水分が減少し水の供給が断たれる と, 水の需給のバランスが崩れて導管内の水柱が切れ る.これが回復することなく水柱が切れた状態が一定 期間続くとやがて枯死に至る. こうした水の枯渴によ る水ストレスが発生すると, 樹木はホルモンの作用で 葉をしおれさせて蒸散作用を停止し, 保身する.

水ストレスの初期段階で，導管内に気泡の発生によ るキャビテーションが起こることが知られている(1). キャビテーションによる衝撃波が $\mathrm{AE}$ (Acoustic

Emission) となることから，この $\mathrm{AE}$ を圧電センサによ って計測することで水ストレスの状態をリアルタイム で知ることができる．これまでも $\mathrm{AE}$ 法により植物の 水ストレス状態をモニタリングする研究が行われてい $ろ^{(2)-(5)}$ が，長期間にわたり渴水状態にして昼夜の $\mathrm{AE}$ を観測した例はない. 
本研究で対象とした種子植物は, 日本の街路樹とし て最も多く使われている環境ストレスに対する耐性が高 いイチョウ（Ginkgo biloba $L)$ ，また乾煤に強いゴム ( Frous elastica ), さらに, 乾燥に弱いトマト ( Lyoopersion esculentum ) の3 種類の植物とした. こ れらに長期間にわたり水ストレスを与えたときの $\mathrm{AE}$ を 測定し, $\mathrm{AE}$ 発生頻度について調べた。

\section{2. 实鉸方法}

\section{$2 \cdot 1$ 実余条件}

2・1・1 イチョウ イチョウは喬木裸子植物に属 し, 給水は仮導管によるが, 仮導管の機能は基本的に 導管と変わらない，約 40 日間給水を断つ短期乾燥実 験を 2002，2003年の夏季に一回ずつ，2001 年の冬季 (Dec.,'01 Mar.,'02) に約 100 日間給水を断つ長期乾燥 実験を1回行った. それぞれの実験で同時に計測する 苗木（3齢) の数は, 使用した $\mathrm{AE}$ 測定器 ( 4 チャン ネル)の制約から，2 3 本ずつとした. 1 本のイチョ ウに対して1 2籄所に AEセンサを設置した. イチョ ウは直径 $23 \mathrm{~cm}$ 高さ $21 \mathrm{~cm}$ のプラスチック製容器 (鉢) に栽培し, 土壤は市販の有機培養土を使用した.

2002年の短期乾燥実験では，3本のイチョウを測定 した. 2本は乾燥用として，1本はコントロール（給 水状態）用に水を 2 日毎に与えたものを用いた. 乾 燥開始から 40 日目に再び水を与え, 水ストレスの回 復を調べた. 2003 年の短期乾燥実験は個体差を調べ るため 2 本とも乾燥用とし, 幹に対向する 2 箇所の位 置にセンサを設置した. 2001 年の長期乾燥実験も同 様に 2 本とし, 乾燥開始から90日目に再び水を与え, $\mathrm{AE}$ 事象数の変化を調べた.

\section{2・1・2 コム ゴムは被子植物の双子葉類で導管} を持つ. 2002年の冬季(Dec.,'02〜Mar,'03) に約 100 日 間給水を断つ乾燥実験を行った. 苗木は 2 本とし，1 本は乾燥用とし，1本はコントロール用に水を数日毎 に与えたものを用いた. ゴムは直径 $15 \mathrm{~cm}$ 高さ $18 \mathrm{~cm}$ のプラスチック製容器(鉢)に栽培し, 土滾は市販の有 機培養土を使用した。

2・1-3 トマト トマトは草本の双子葉類で導管を 持つ. 2003 年の秋季にトマトの乾燥実験を行った. トマトは縋 $58 \mathrm{~cm}$, 横 $18 \mathrm{~cm}$, 高さ $19 \mathrm{~cm}$ のプラスチッ ク製容器 (プランター)に2 本栽培し, 土壤は市販の有 機培䖯土を使用した。乾㫵開始前に 20 日間ほぼ毎日 水を与え（コントロール期），水ストレスを受けてい
ない状態での測定を行い，その後 14 日間給水を断ち 乾燥実験を行った.

表 1 に全ての実験の測定条件を示す. なお, 表中使 用植物の括弧内のローマ数字はイチョウの番号, 文字 は水ストレス処置の有無を表している (C: control, $\mathrm{D}$ : drought) . また, 実験期間の括弧内のアラビア数 字は乾燥期間を表しており，いずれも十分給水してか ら乾燥を開始した.

\begin{tabular}{|l|l|c|}
\hline Season & Plant (Treatment) & Period \\
\hline 2001 winter & Ginkgo (VID, VII) & $99(89)$ \\
\hline 2002 summer & Ginkgo ( I C, I D, II D) & $43(39)$ \\
\hline 2002 winter & Indian rubber fig (C, D) & $92(92)$ \\
\hline 2003 summer & Ginkgo (IVD, VD) & $41(41)$ \\
\hline 2003 autmun & Tomato (D, D) & $36(14)$ \\
\hline
\end{tabular}

Table.1 Condition of the experiment

$2 \cdot 2$ 実邪装置実験の模式図を図 1 に示す.実 験室内に簡易温室を設置した. 昼夜にわたり計測を行 った. 実験室内は暗幕を用いて遮光し，12 時間育成 灯（メタルハライドランプ $250 \mathrm{~W}$, 岩崎電気製)を 2 基点灯させることで昼間とした. 室温は $25 \sim 28^{\circ} \mathrm{C}$ と した. 湿度は夏季の実験においては 40\% 55\%，冬季 の実験においては15〜30\%とした.

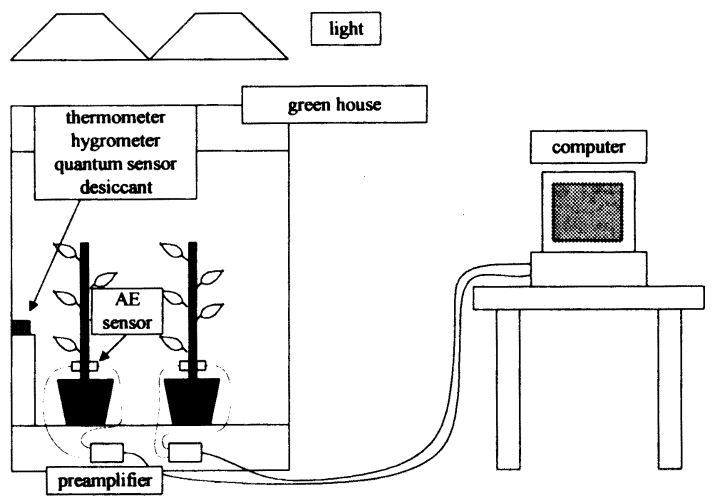

Fig.1 Schematic of measuring system

\subsection{AE 計测}

数百本ある導管内で発生するキャビテーションに伴 う $\mathrm{AE}$ エネルギの放出は微弱であり, 細胞組織内での 减衰も大きいため, $\mathrm{AE}$ の伝播距離は数センチメート ルに留まる.このため 1 箅所で発生した AEを近接し た複数のセンサで同時に計測出来ないことも多い，直 


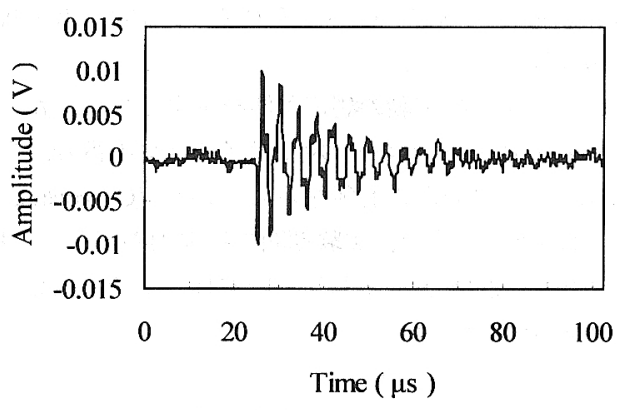

Fig. 2 Typical AE wave form
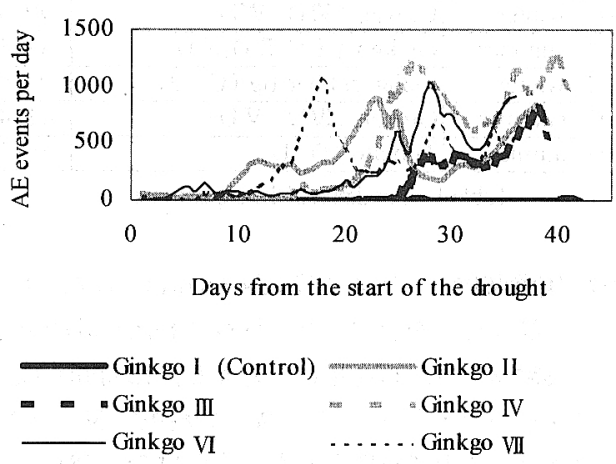

Fig. 3 Relation between AE event and lapse of time for short time data

径約 $10 \mathrm{~mm}$ の幹に対向して2 個のセンサを設置した場 合でも，1個のセンサ直下で発生した AE 事象が両方 のセンサで同時計测されていないことがある. セン サは 300kHz 共振型 $\mathrm{AE}$ セン ( M31，富士セラミック ス社製)を用いた，センサ設置位置は，土壤表面から 約 $5 \mathrm{~cm}$ の位置とし，2箇所に AEセンサを設置する場 合は，幹に対向する 2 箇所の位置に設置した. AEセ ンサの取り付けは，幹との間にゼリーを介してバネで 圧着した. 押付力は $8.8 \mathrm{~N}$ とした，樹皮表面は平坦で はないためセンサの圧着状態が異なるほか，伝播経路 によって $\mathrm{AE}$ 波形そのものが若千変化する.このため, センサの校正は左右二つのセンサから等距離の点でセ ンサと同一水平面から高さ $20 \mathrm{~mm}$ の位置においてシャ 一プペンシルの芯を幹の表面で数回圧折し, その最大 振幅が一定となるようセンサの取り付けを微調整した。

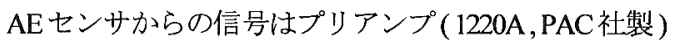
で 40dB 増幅し, $\mathrm{AE}$ 測定器 (Disp-80, PAC 社製) に取 り込み，PCにより演算処理を行った。

なお，しきい值は高周波ノイズより $1 \mathrm{~dB}$ 高く設定 した. 波形を周波数解析して, パルス状波形，数十 $\mathrm{k}$ $\mathrm{Hz}$ 以下の低周波を持つものおよび明らかにノイズと 判定された波形を除き，ここでは $\mathrm{AE}$ 信号と見なされ
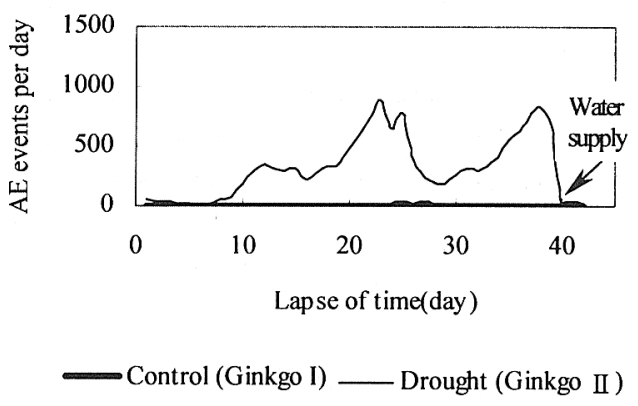

Fig 4 AE events-lapse of time curve (2002 summer, Ginkgo I ,Ginkgo II)

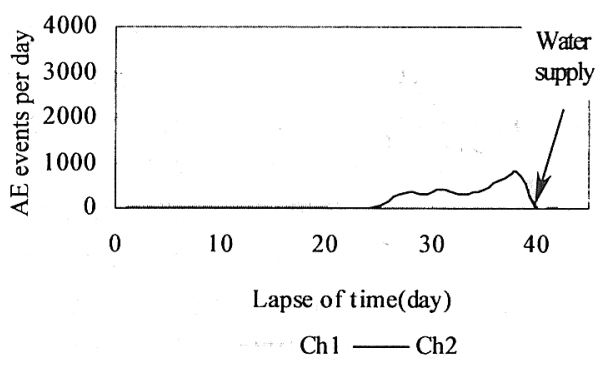

Fig.5 AE events-lapse of time curve

(2002 summer, Ginkgo III)

る波形のみを計数している．図2に植物から発生する $\mathrm{AE}$ 信号の一例を示す.

\section{3. 実験結果と考察}

\section{3・1 短期乾媬実験による $\mathrm{AE}$ 事象数の変化}

3・1・1イチョウ イチョウの短期実験データを図 3 に示寸. $\mathrm{AE}$ 事象数そのものは個体差が大きいが, 全体的な傾向として乾燥開始後 20 日前後で AEが増 加しているため，この時期にキャビテーションが増加 していると考えられる.この中の代表的な例を示す. 网 4,5 は2002年夏季のイチョウの実験における 1 日当 りの $\mathrm{AE}$ 事象数と経過日数との関係を表す.

水を与え続けているイチョウI（コントロール）か らはAEは発生しない（図 4）。一方，乾燥させたイ チョウ II,IIIでは，乾燥初期に AE はほとんど発生しな いが，徐々に増加し，ピークを迎えた後，一時減少す る.これはイチョウが何らかのホルモンを分必して導 管内の水分調節を行い，一度増えたキャビテーション の発生率を下げたためと考えられるが，詳細は明らか でない. 図 5 に示す ch1,2は対向する 2 箇所の位置に 設置した AEセンサを示している. AEの増加傾向は 同じものの, 発生数は3 倍程度の差異が生じた. 導管 
は茥の外周に存在するので, 同じ高さにセンサを設置 したとしても，検出される発生数は異なる.

なお，イチョウの葉は落葉したものの，実験後に給 水を続けた結果，翌年新芽を出した。

3·1・2 トマト 2003年秋季に行ったトマトの実験 において 1 日毎の $\mathrm{AE}$ 事象数の変化の一例を図6に示 す.グラフでは乾燥開始日を0日目とし，それ以前の 水を与えていた時期（コントロール期）はマイナスで 表した.コントロール期では AE はほとんど発生して いない: 乾燥開始後も9日目までAEはほとん゙発生 していないが，10日目以降急激に増加し，14日目に 茥の膨王が低下してセンサが保持できなくなったため， 実験を終了した.AE増加の割合はイチョウに比べ著 しい.
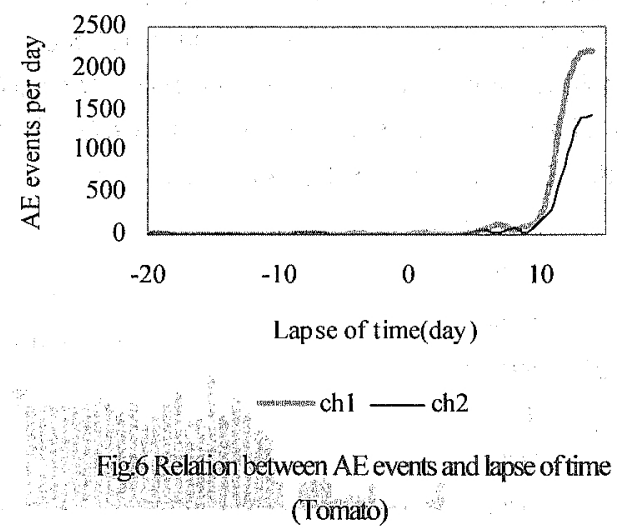

\section{2 長期乾燥実騟による $\mathrm{AE}$ 事像数の変化}

3·2・1 イチョウ 図7は2001年冬季のイチョウVI, VIIついての実験における1日毎の $\mathrm{AE}$ 事象数を示す。 乾燥開始から 40 日前後までは短期乾燥実験と同様な 傾向を示しているが，45～50 日目に著しく $\mathrm{AE} か ゙$ 増加 し，その後急激に減少寸る. 減少後は，それ以前の増 減を繰り返可傾向とは明らかに異なっており，また図 4に示したような水を与えた反応とも異なっている。 乾煰開始から90日月に水を与えたが変化はなく，俵

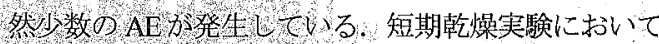

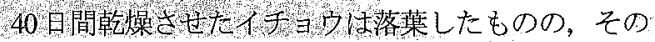
後給水を続けた結果，翌年新芽を出したが，長期乾燥 実験で使用したイチョウは枯死した。おそらく 45〜 50 日目の急激な $\mathrm{AE}$ 事象数の増加時に多くの導管内の 水柱が分断されて，枯死したものと思われる。

3-2-2 ゴム 2002 年冬季のゴムの実験における1 日当りの $\mathrm{AE}$ 事象数安図 8 に示寸。

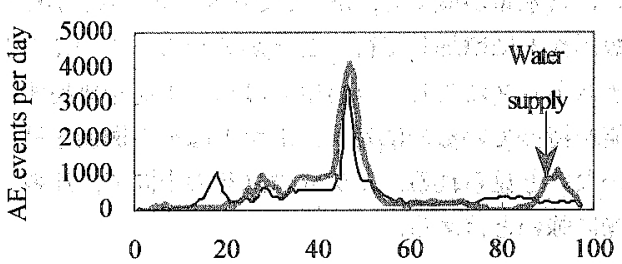

Days from the start of the drought

Ginkgo VI — Ginkgo VII

Fig. 7 AE events-lapse of time curve (2001 winter, Ginkgo VI, VI)

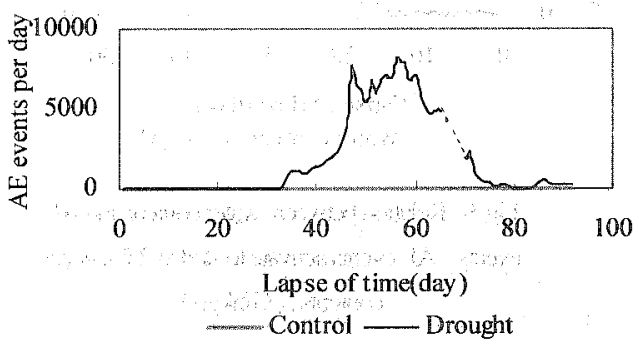

Fig. 8 AE events-lapse of time curve (2002 winter, Indian rubber fig)

イチョウと同様, コントロールては $\mathrm{AE}$ の発生は見 られない，乾燥させたゴムでは 35 目目あたりから $\mathrm{AE}$ が増え始め，乙の後急激に増加し，50〜60日目にか けて 1 日に5000を超える AEが発生した。60日目以 降，AEは徐々に減少していき，75日目にはほとんど 現れなくなる:使用したゴムは辰期乾燥実験のイチョ ウ同様，その後葉をつけることはなかつた。75日目 以降， $\mathrm{AE}$ は少ないが 1 日に500近くのAEが見られ， コントロールの傾向とは異なっている.このようにゴ ムの $\mathrm{AE}$ 事象の発生傾向はイチョウと同様である。な お，途中測定できなかった期間を図中に波線で示した。

$3 \cdot 3$ 土壤の含水率とA登华との閏係 乾燥は土 培中の水分量の減少を意味する. そこで土壤の含水率 と $\mathrm{AE}$ 発生との関孫夺求めた。図9～图11に示すよう にイチョウ，ゴム，トマトはいずれも乾燥開始時点で 50\%の含水率を示していたが，20\%まで減少する時間 はゴムとトマトが 10日間，イチョウが20日間となっ ている，イチョウとトマトは含水率が $20 \%$ に達した 時点で $\mathrm{AE}$ 急増が諗められた。イチョウはさらに含 水率が減少しても AEは20日以上発生し続故たが， トマトは数日 $\mathrm{AE}$ が発生したのち枯死した。 それに対 してゴムは20\%の含水率で AE は発生しなか力た。さ 
らに含水量が減少し，0\%になり5日経た後，AE事象 数が徐ヶに増加して行くことが分かる.このことから， 水ストレスに対し，ゴムはしばらく生命を維持する機 能を持っているのに対し，トマトはその機能を持って いないと見られる.イチョウはその中間で, 比較的乾 燥に強いと言える。

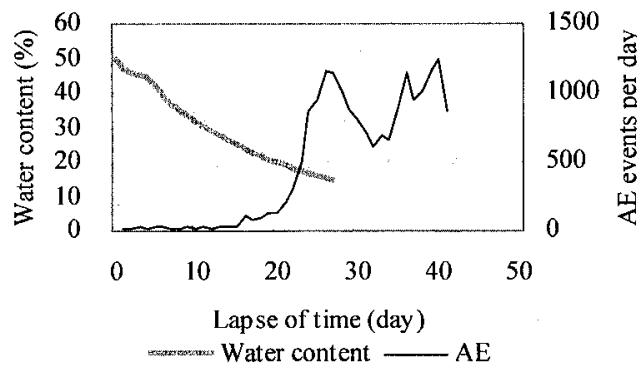

Fig. 9 Relation between water content and $\mathrm{AE}$ events. AE events activate to start at $25 \%$ water contents . (Ginkgo)

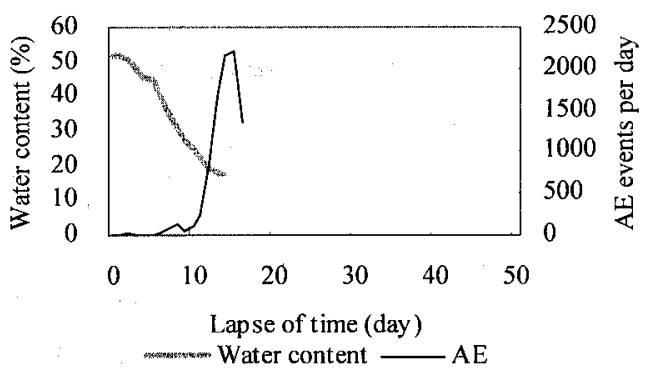

Fig. 10 Relation between water content and $\mathrm{AE}$ events. AE events activate to start at $40 \%$ water contents. (Tomato)

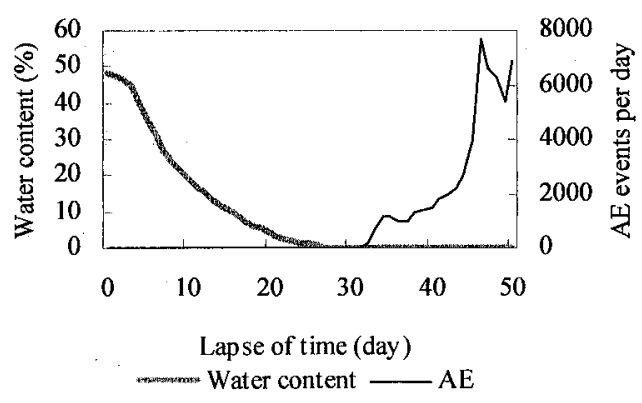

Fig. 11 Relation between water content and $\mathrm{AE}$ events. AE events activate to start at $0 \%$ water contents (Indian rubber fig)
3.4 AE 事象出現の昼夜間の比較 キャビテーシ ヨンは植物の蒸散による水の損失が原因で起こるため, 通常は蒸散が活発な日中に多く発生し，光が当たらな くなる夜間にはあまり発生しないと考えられるが，水

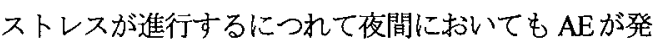
生した.

図 12 に 2002年夏季のイチョウ $1 \mathrm{H} の 1$ 日当りの $\mathrm{AE}$ が夜間に発生する割合を示す。乾燥初期に AEは主に 日中に発生するが，徐々に夜間に発生する割合が増加 し，20日目前後にはおよそ40\%となる. 図 5 と比較 すると，1 日当りの $\mathrm{AE}$ 事象数が急激に増加する以前 に，夜間の $\mathrm{AE}$ 事象数の割合が堌加する.このとき既 にイチョウは多くの水ストレスを受けており，ホルモ ンの作用で葉からの蒸散作用定停止したことから, 夜 間の $\mathrm{AE}$ 発生の割合が増えたものと考えられる. 20 日 目以降は夜間の割合が $40 \%$ の状態が続き，それ以上夜 間の割合が増えることはなかった４４日目に水を与 えた後は，夜間の $\mathrm{AE}$ はほとんど見られなくなり乾燥 前の状態に戻った. 夜間に発生する $\mathrm{AE}$ 事象数の割合 を調べることにより，晹水状態にあることをより早く 知ることが出来る.

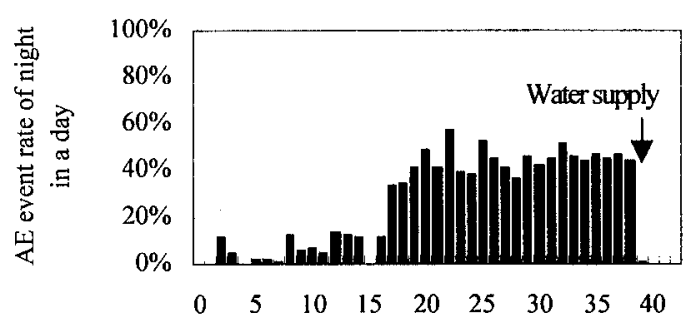

Lapse of time (day)

Fig. 12 AE event rate-lapse of time curve (night 2002 summer, Ginkgo III )

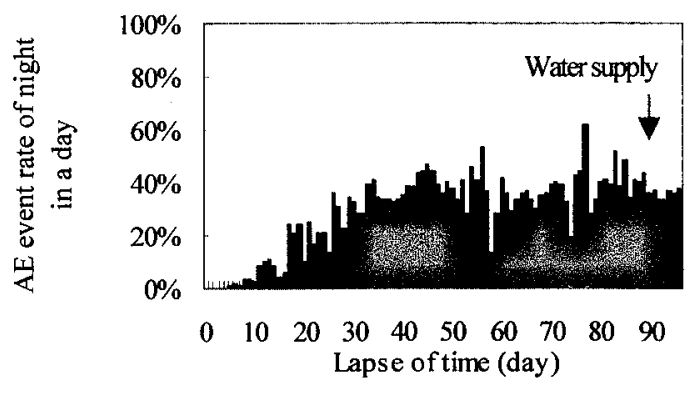

Fig. 13 AE event rate-lapse of time curve (night 2001 winter, Ginkgo VI) 
次に 2001 年冬のイチョウVIで AEが夜間に現れた 割合を図 13 に示す。 40 日目までは日中の AEの割合 が若干多いものの，図 12 の結果と同様の傾向を示し ている.しかし，45〜50日目の1日当たりの $\mathrm{AE}$ 事象 数が急激に增加した後（図 7），急激に減少した状態 においても昼夜の割合はほぼ $6: 4$ のままであり（図 13），90日目に水を与えても夜間の AE 事象は減少し ない.

植物体内での水の移動（吸水）は，導管内部の水ポ テンシャルが十壌中のそれよりも低い時に生じる. 根 による吸水方法として, 地上部の蒸散が引き金となっ て起こる受動的吸水と, 根が土壌から積極的に楉質, カリウム, ナトリウム等を取り込むことで根圧を生じ させることにより吸水を行う能動的吸水がある. 水を 与えると，土壤中の水ポテンシャルが高くなるため， 水の移動が生じるはずである. しかしながら，長期の 乾燥実験において，水の移動が起きなかったことを示 している.このことから，ある一定期間渴水状態にお かれた植物は，根における能動的吸水のための機能を 失い，その後，吸水を行うことができなくなると考え られる.

\section{4. 結言}

本研究は， 3 種類の植物に対して長期間渴水状態に さらした水ストレス期間と植物体内で起こる物理的変 化の計測量である $\mathrm{AE}$ との関係について調べた.

その結果, 以下の結論を得た。

（1）イチョウ,ゴム,トマトを対象に，土壤への水分の 供給を停止することで水ストレスを与えた結果, いずれの植物においても乾燥の経過と共に AEが 発生した.

（2）乾燥耐性が高いゴムは，土壤の含水率が $0 \%$ とな ってもしばらくは AEが発生しないが，乾燥而性 が低いトマトは, 含水率が 20\%に達した時点で

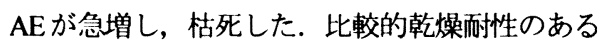

イチョウは, $\mathrm{AE} か ゙$ 発生してからしばらく経過し た後も, 水を与え $\mathrm{AE}$ の発生が止まる場合は, 葉 が落葉したとしても，枯死しないことがわかった.

(3) イチョウとゴムにおいて, 乾燥期間中 $\mathrm{AE} の 一$ 時 的な减少が見られた.これは, 植物自身が自己防 衛のため何らかの方法で導管内の水分調節を行っ たものと考えられる.

(4) イチョウとゴムで枯死に至るまで乾燥を続けた結 果, イチョウでは乾燥開始より 45〜 50日目に, ゴムでば45〜60日目にそれぞれ $\mathrm{AE}$ 事象数に著し い増加が見られ，その後急激に减少した. 減少後 も $\mathrm{AE}$ が生じ, 水を与えても $\mathrm{AE}$ の発生は停止し なかった. イチョウ, ゴムともに後日再生するこ とがなかったことから，長期的に渴水状態におか れることにより，根における吸水機能が失われた と考えられる.

\section{文薣}

(1) J. A. Milbum, et al: Planta,Vol.69, pp 43-52,(1966)

(2) Robert A., et al: Joumal of Acoustic Emission, Vol. 9, No.3, pp 42-46(1990)

(3) Keiichi Sato, et al: Joumal of Acoustic Emission, Vol. 13, No.12, pp 42-46(1995)

(4) G. E. Jackson, et al: Tree Physiology Vol. 15, pp 791-798 (1995)

(5) J. S. Sperty et al: Tree Physiology Vol. 17, pp 275-280, (1997)

(6) M. T. Tyree: Journal of Experimental Botany, Vol. 48, No.315, pp 1753-1765 (1997) 